\title{
A renewed tool kit to explore Chlamydia pathogenesis: from molecular genetics to new infection models [version 1; peer
}

\section{review: 3 approved]}

\author{
Lee Dolat, Raphael H Valdivia(ib)
}

Department of Molecular Genetics and Microbiology, Duke University Medical Center, Durham, USA

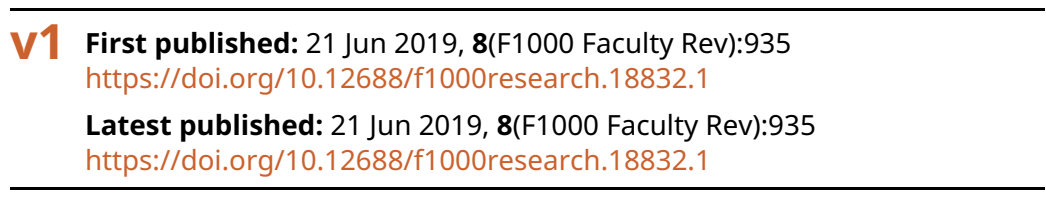

\section{Abstract}

Chlamydia trachomatis is the most prevalent sexually transmitted bacterial pathogen and the leading cause of preventable blindness in the developing world. C. trachomatis invades the epithelium of the conjunctiva and genital tract and replicates within an intracellular membrane-bound compartment termed the inclusion. To invade and replicate in mammalian cells, Chlamydia remodels epithelial surfaces by reorganizing the cytoskeleton and cell-cell adhesions, reprograms membrane trafficking, and modulates cell signaling to dampen innate immune responses. If the infection ascends to the upper female genital tract, it can result in pelvic inflammatory disease and tissue scarring. C. trachomatis infections are associated with infertility, ectopic pregnancies, the fibrotic disorder endometriosis, and potentially cancers of the cervix and uterus. Unfortunately, the molecular mechanisms by which this clinically important human pathogen subverts host cellular functions and causes disease have remained relatively poorly understood because of the dearth of molecular genetic tools to study Chlamydiae and limitations of both in vivo and in vitro infection models. In this review, we discuss recent advances in the experimental molecular tool kit available to dissect $C$. trachomatis infections with a special focus on Chlamydia-induced epithelial barrier disruption by regulating the structure, function, and dynamics of epithelial cell-cell junctions.

\section{Keywords}

Chlamydia, pathogenesis, genetics, cell-cell junctions, organoids, infection models

\section{Open Peer Review}

Approval Status

1

2

3

version 1

21 Jun 2019

Faculty Reviews are review articles written by the prestigious Members of Faculty Opinions. The articles are commissioned and peer reviewed before publication to ensure that the final, published version is comprehensive and accessible. The reviewers who approved the final version are listed with their names and affiliations.

1. Peter Timms, University of the Sunshine

Coast, Queensland, Australia

2. Kenneth Fields, University of Kentucky

College of Medicine, Kentucky, USA

3. Ming Tan, University of California, Irvine, California, USA

Any comments on the article can be found at the end of the article. 
Corresponding author: Raphael H Valdivia (valdi001@mc.duke.edu)

Author roles: Dolat L: Writing - Review \& Editing; Valdivia RH: Writing - Review \& Editing

Competing interests: $\mathrm{RHV}$ is a member of the scientific advisory board of Meridian Biosciences. LD declares that he has no competing interests.

Grant information: This work received funding support from the National Institute of Allergy and Infectious Diseases (grants R01AI134891 and F32AI138372).

The funders had no role in study design, data collection and analysis, decision to publish, or preparation of the manuscript.

Copyright: $\odot 2019$ Dolat L and Valdivia RH. This is an open access article distributed under the terms of the Creative Commons Attribution License, which permits unrestricted use, distribution, and reproduction in any medium, provided the original work is properly cited.

How to cite this article: Dolat $L$ and Valdivia RH. A renewed tool kit to explore Chlamydia pathogenesis: from molecular genetics to new infection models [version 1; peer review: 3 approved] F1000Research 2019, 8(F1000 Faculty Rev):935

https://doi.org/10.12688/f1000research.18832.1

First published: 21 Jun 2019, 8(F1000 Faculty Rev):935 https://doi.org/10.12688/f1000research.18832.1 


\section{Introduction}

The order Chlamydiae are obligate intracellular pathogens of eukaryotic cells. These bacteria have reduced genomes and display biphasic developmental stages that alternate between distinct extracellular and intracellular forms ${ }^{1,2}$. Eleven pathogenic Chlamydia species infect vertebrate animals and display tissue-specific tropism ${ }^{3}$. The elementary body (EB) is the environmentally stable form of the pathogen that binds and invades target cells. The EB then transitions into the larger intracellular reticulate body (RB) form. RBs replicate and secrete proteins across the parasitophorous membrane-bound vacuole ("inclusion") to modulate multiple host cellular functions that benefit the bacterium ${ }^{4}$.

All Chlamydiae encode a type III secretion (T3S) system to deliver a defined cohort of bacterial proteins ("T3S effectors") directly into the host cell ${ }^{5}$. The Chlamydia trachomatis EB $\mathrm{T} 3 \mathrm{~S}$ effectors modify the cytoskeleton and stimulate bacterial uptake into a membrane-bound vacuole that is rapidly segregated from degradative trafficking pathways (Figure 1A $)^{6,7}$.
A subset of T3S effectors are inserted into the inclusion membrane. These inclusion membrane proteins (Incs), which are secreted throughout the infectious life cycle, are diverse $(\sim 5 \%$ of the total coding potential of $C$. trachomatis) and their molecular function is just beginning to be understood ${ }^{8}$. For instance, Incs co-opt the microtubule motor protein dynein to transport nascent inclusions along microtubules toward the centrosome (Figure 1A) $)^{9}$. Along the way, the inclusion membrane is modified by lipid kinases, which may be important for evasion of endolysosomal compartments ${ }^{10}$. Some Incs contain SNARE (soluble $\mathrm{N}$-ethylmaleimide-sensitive factor attachment protein receptor)-like domains that coordinate fusion between inclusions and other membrane vesicles ${ }^{11}$, whereas others promote the recruitment of the endoplasmic reticulum and Golgi complex to the vicinity of the inclusion, possibly to intercept lipid-rich vesicles to support Chlamydia replication (Figure 1A) ${ }^{12-14}$. As the inclusion matures, it is increasingly encased by a network of F-actin, microtubules, intermediate filaments, and septins, which help confine the bacteria within the inclusion and limit recognition of bacterial products by innate immune sensors ${ }^{15-17}$.

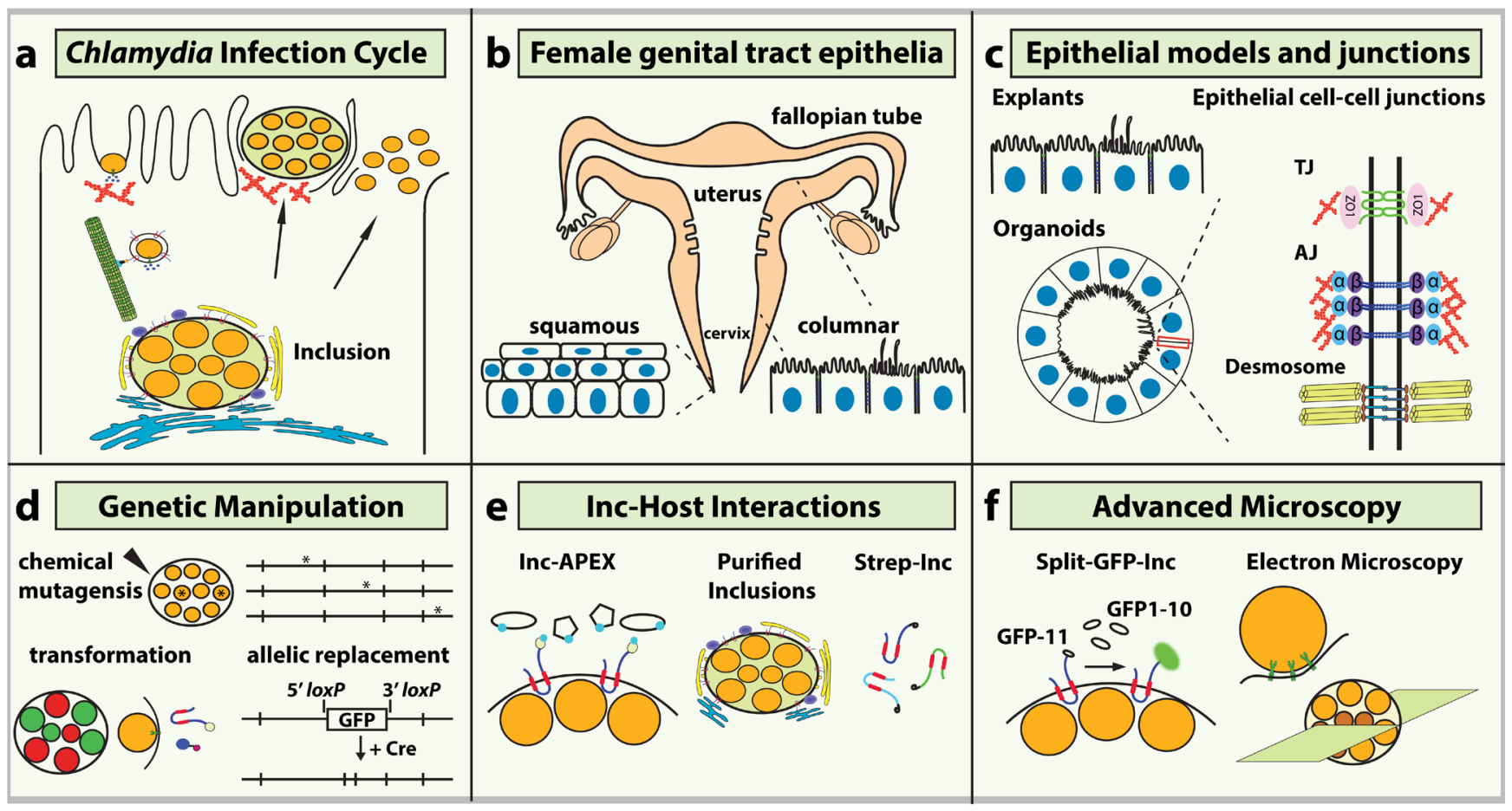

Figure 1. Recent advances in the molecular tool kit and infection models to explore Chlamydia infection. (a) The Chlamydia trachomatis infection cycle. The elementary body (EB) form of the bacteria remodels actin filaments (red) during entry and traffics along microtubules (green) to the perinuclear region. Inclusion membrane proteins (Incs) recruit the Golgi complex (yellow) and endoplasmic reticulum (blue) At the end of the intracellular cycle, the inclusion exits via actin-dependent extrusion or cell lysis. (b) Anatomy of the female genital tract and epithelial cell organization in the lower and upper tract. (c) New epithelial model systems (left) and schematic of polarized columnar epithelial cell-cell junctions (right). Tight junction (TJ) and adherens junction (AJ) complexes recruit adaptor proteins that connect to the actin cytoskeleton (red); desmosomes interact with intermediate filaments (yellow). (d) New genetic tools for $C$. trachomatis include chemical mutagenesis and whole-genome sequencing to identify mutations and plasmid transformation to generate fluorescent reporter strains, tagged effectors, and targeted gene disruption via allelic replacement. (e) New proteomic-based strategies to identify host proteins that interact with Chlamydia Incs. Incs tagged with the enzyme ascorbate peroxidase (APEX) (left) can ligate biotin-phenol on host proteins in close proximity. Purified inclusions (middle) and Strep-tagged Incs (right) were used to identify host proteins recruited to the inclusion and Inc-host protein interactions, respectively. (f) Summary of advanced microscopy approaches to visualize Chlamydia effector localization using the Split-green fluorescent protein (Split-GFP) system (left), the structure of the T3S apparatus in contact with the plasma membrane (middle), and reticulate body (RB)-to-EB conversion (right). ZO-1, zona occludens 1. 
Mid-stage through the infectious cycle, RBs transition back to EBs such that at the end of the cycle the infectious bacteria are released either by an actin-dependent extrusion process whereby the intact inclusion is exocytosed from the cell or by lysis of the host cell which requires the cleavage of cytoskeletal elements and nuclear rupture ${ }^{18,19}$.

Much of our understanding of the cell biology of how Chlamydia interacts with target cells and the molecular mechanisms it uses to manipulate cellular processes is based on observations made in infected cancer cell lines, which in addition to being metabolically and genetically adapted for proliferation, lack positional cues that are available only in the context of tissues. For example, polarized columnar epithelial cells, the in vivo target of $C$. trachomatis, display a spatial organization of organelles and cell signaling pathways that intimately intertwine stable cell-cell junctions to epithelial function and proliferation (Figure 1B, C). Such structures and signaling networks are not present-or properly wired-in common cell lines used in Chlamydia research. Fortunately, more sophisticated infection models, coupled with the increasing ability to genetically manipulate Chlamydia, now provide a renewed tool kit to better understand how these pathogens interact with their intact animal hosts.

\section{An expansion of the molecular tool kits available for Chlamydia research}

The greatest single advance in Chlamydia biology over the past decade has been the development of methods to perform genetic analysis of $C$. trachomatis mutants and increasingly robust molecular genetic tools to transform Chlamydia with

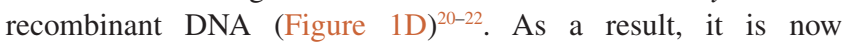
possible to perform targeted gene inactivation and plasmidbased complementation of chromosomal mutations ${ }^{22-25}$. The ability to express exogenous proteins, epitope tags, and fluorescent and other reporter proteins in Chlamydia has also expanded the repertoire of possible technologies that can be applied to study the Chlamydia-host interface ${ }^{26,27}$. For instance, Incs fused to enzymes that enable the biotinylation of proteins identified host factors that are in proximity to the inclusion membrane by affinity capture of biotinylated proteins coupled with tandem mass spectrometry (Figure $1 \mathrm{E})^{28,29}$.

Two recent studies using quantitative proteomics identified host proteins that interact with Incs and host proteins that are preferentially recruited to the inclusion (Figure 1E). In one study, intact inclusions were isolated and all associated host proteins were identified and quantified by stable isotope labeling by/with amino acids in cell culture (SILAC)based mass spectrometry ${ }^{30}$. In parallel, a large-scale study identified previously unknown host-binding partners for nearly two thirds of the predicted Incs. Using affinity purification of Strep-tagged Incs coupled to quantitative mass spectroscopy, a second study provided a blueprint for Inc-host interactions ${ }^{31}$. The different but complementary approaches presented new clues as to the potential mechanisms used by Chlamydia to subvert various aspects of host cell biology.
The advances in genetic and biochemical approaches have been further complemented with high-resolution microscopy (Figure 1F). The localization and dynamics of Chlamydia T3S effectors can now be visualized live by using the split-green fluorescent protein (split-GFP) system ${ }^{32}$, an approach that relies on fusing the effector with the 16-amino acid GFP-11 $\beta$-strand and infecting cells expressing the GFP1-10 $\beta$-strands. Upon secretion and complementation, the GFP $\beta$-barrel properly folds and fluoresces (Figure $1 \mathrm{~F})^{33}$. Furthermore, the application of cryo-electron microscopy revealed with unprecedented resolution that the Chlamydia T3S apparatus changes shape and polarizes toward host cell membrane ${ }^{34}$. Similarly, applied serial block-face scanning electron microscopy temporally characterized the process of RB-to-EB conversion during the infection cycle (Figure 1F) ${ }^{35}$.

\section{Recent advances in cell culture infection models}

Urogenital serovars of $C$. trachomatis target the mucosal epithelium. In the female genital tract, the infection typically begins in the endocervix before ascending to the endometrium and fallopian tubes ${ }^{36}$. These tissues are comprised largely of polarized columnar epithelial cells with a rich diversity in form and function which is not readily recapitulated in two-dimensional culture settings $\mathrm{s}^{37}$. Thus, new in vitro models that more accurately reconstruct the organization and complexity of the genital tract are essential to better understand the full impact of Chlamydia infection on the epithelial physiology.

Wyrick and colleagues first described key differences in Chlamydia growth in polarized epithelial cells ${ }^{38}$. Human endometrial epithelial cancer cells polarized on collagencoated microcarrier beads significantly enhanced the growth of C. trachomatis serovar E, independent of EB attachment efficiency, compared with non-polarized cells ${ }^{38}$. Infections in polarized enterocytes show that the inclusion preferentially captures lipid-rich exocytic vesicles that are specifically trafficked toward the basolateral membrane, suggesting that Chlamydia has adapted to grow in a polarized environment ${ }^{39}$. More recently, a human endocervical epithelial cell line (A2EN cells) derived from a healthy patient sample has been shown to polarize, secrete mucin, and express pro-inflammatory cytokines during infection ${ }^{40,41}$.

Meyer and colleagues pioneered the use of ex vivo organotypic cultures and a novel fallopian tube organoid (FTO) model to investigate $C$. trachomatis infection in primary human epithelia ${ }^{42,43}$. Partially dissected tissue from the ectocervix and fallopian tube-representing the lower and upper genital tracts, respectively - has been cultured ex vivo and infected with Chlamydia ${ }^{42,43}$. These models were recently simplified by culturing isolated tubal epithelial cells in a three-dimensional matrix, generating self-renewing FTOs (Figure 1C) 44 $^{4}$ FTOs consist of secretory and ciliated epithelia, the two most common epithelial cell types in the fallopian tube, and more accurately recapitulate fallopian tube epithelial architecture. Acute infection in FTOs produced a strong inflammatory response 
while long-term and chronic infection increased epithelial stemness and proliferation and altered the methylation status of genes associated with aging. The latter results provide new insights into the long-term effects of Chlamydia infection on epithelial tissue homeostasis and the correlation between infection and cell proliferation ${ }^{45}$.

\section{The epithelium of the female genital tract}

Ultrastructural analysis of the lower female genital tract shows squamous ectocervical epithelia and columnar endocervical epithelia, which display differential organization of cell-cell junctions ${ }^{37}$. The endometrium resembles columnar epithelia of the endocervix with increased epithelial diversity that includes ciliated and secretory cells and hormonally responsive and crypt-like glandular epithelia (Figure 1B) ${ }^{46}$.

Ultimately, the protective function of the epithelium is accomplished through the formation of intercellular junctions, molecular complexes that link up with the cytoskeleton to reinforce epithelial integrity. However, unlike other epithelial tissues, the endometrium exhibits remarkable changes during hormonal cycles and pregnancy, directly altering the expression profile of cell-cell junction proteins, their organization, dynamics, and barrier function ${ }^{46,47}$. In columnar epithelia, the three main classes of intercellular junctions are the tight junctions (TJs), adherens junctions (AJs), and desmosomes (Figure 1C) ) $^{48}$. Although their function as molecular linkages has long been appreciated, newer studies have uncovered critical roles in transducing cell signaling pathways during tissue damage, repair, and pathogenic infection ${ }^{49}$.

At the apex of the lateral cell membrane, TJs maintain a fence that physically separates the apical and basolateral membranes while gating the flux of ions and solutes through the paracellular space $^{50}$. Three families of transmembrane proteinsclaudins, occludins, and junctional adhesion molecules (JAMs)—form homotypic interactions between adjacent cells. Adaptor proteins - that is, zona occludens 1-3 (ZO-1-3) - bind to their cytoplasmic tails and scaffold the recruitment of the polarity complex, which specifies apical membrane identity, and actin and microtubules to regulate TJ dynamics and stability $^{50}$.

AJs along the basolateral membrane are formed by homotypic interaction between cadherins, calcium-dependent transmembrane proteins ${ }^{51}$. The adaptor proteins $\alpha$ - and $\beta$-catenin bind to cadherins and the actin cytoskeleton to reinforce AJ stability ${ }^{52}$. AJ components, including $\beta$-catenin and others such as YES-associated protein (YAP), also function as transcription factors but are excluded from the nucleus through their association with stable $\mathrm{AJs}^{53}$. AJ assembly is initially mediated by nectins, calcium-independent adhesion molecules, that also bind to $\mathrm{AJ}$ and $\mathrm{TJ}$ adaptor proteins ${ }^{54,55}$. The related but structurally distinct desmosomes are composed of a second class of cadherins-desmogleins and desmocollins-that connect to intermediate filaments, such as keratins, rigid cytoskeletal elements that provide additional structural support. Indeed, these strong junctions are thought to resist mechanical stress and are essential for the maintenance of epithelial integrity ${ }^{56}$.
Many pathogenic viruses and bacteria have evolved diverse strategies to subvert cell-cell adhesions to gain entry into host cells or penetrate further into the underlying tissue ${ }^{57}$. For example, Listeria monocytogenes surface protein InlA binds to E-cadherin and the hepatitis $\mathrm{C}$ virus binds to claudin-1 to promote their internalization ${ }^{58,59}$. The enteropathogenic Escherichia coli T3S effector EspF disrupts TJs and leads to a loss of epithelial barrier function ${ }^{60}$. Importantly, these perturbations to cell-cell junctions can elicit an immune response as lumenal bacteria and toxins leak into the underlying tissue ${ }^{61}$.

\section{Chlamydia interactions with the epithelial surface}

Initial observations in tumor cell lines indicated that C. trachomatis infection can impact cell-cell junctions. Chlamydia infections disrupt N-cadherin-based AJs in HeLa cells. Gaps were observed between Chlamydia-infected cells and $\beta$-catenin relocalized to inclusions based on indirect immunofluorescence $^{62}$. These basic observations in twodimensional cell culture were detailed further in an ex vivo fallopian tube infection model. Infection with a $C$. trachomatis lymphogranuloma venereum (LGV) biovar disrupted epithelial polarity and cell-cell junction organization through a Wntdriven paracrine signaling pathway ${ }^{42}$. The Wnt pathway consists of secreted glycoproteins that bind to the Frizzled and LRP5/6 receptors, activating downstream signals to regulate tissue organization through cell fate determination, polarity formation, and cell growth ${ }^{63}$. Activation of the canonical pathway disrupts the "destruction complex", stabilizing the Wnt effector $\beta$-catenin and allowing its translocation to the nucleus, where it activates target genes ${ }^{63}$. In fallopian tube epithelia, $\beta$-catenin translocates to the inclusion and a component of the destruction complex, adenomatous polyposis coli (APC), shows more diffuse cytoplasmic localization. Notably, the localization of these Wnt effectors also changed in neighboring uninfected cells but was rescued upon the addition of Wnt inhibitors, suggesting that infection can alter tissue-level Wnt signaling programs ${ }^{42}$. More recently, pharmacological inhibition of Wnt signaling in endometrial epithelial cells resulted in smaller and aberrant inclusions and significantly reduced the production of $\mathrm{EBs}^{64}$.

Chlamydia pneumoniae, the human respiratory pathogen and causative agent of roughly 4 to $6 \%$ of community-acquired pneumonia $^{65}$, also targets effectors of the Wnt pathway. The C. pneumoniae Inc Cpn1027 interacts with and may recruit the Wnt effectors Caprin2 and glycogen synthesis kinase 3 (GSK3) to the inclusion ${ }^{66}$. The $C$. trachomatis T3S effector TepP regulates GSK3 $\beta$ recruitment to nascent inclusions in endocervical epithelial cells ${ }^{10}$, but it is unclear whether these effectors regulate $\mathrm{Wnt}$ in the appropriate tissue context. In endothelial cells, C. pneumoniae infection also promotes vascular endothelial (VE)-cadherin phosphorylation on $\mathrm{Y}_{658}{ }^{67}$, a residue that can control $\mathrm{AJ}$ organization and barrier function ${ }^{68}$. The actin-binding protein EPS8, which is recruited to nascent inclusions during invasion and interacts with phosphorylated peptides derived from the T3S effector Tarp, also binds to VE-cadherin, alpha-catenin, and TJ components to control junction organization ${ }^{69-72}$. These results suggest that Chlamydia may secrete effectors that can target components of cell-cell junctions and cell signaling pathways that regulate junction organization. 
Chlamydia muridarum, a mouse-adapted Chlamydia, also alters the composition of TJ proteins in mouse oviduct epithelial cells $^{73}$. Infection with $C$. muridarum decreases the expression of ZO-1, claudin-1/2, occludin, and JAM-1 while upregulating the expression of claudin-3 and claudin-4. Accordingly, C. muridarum infection alters transepithelial electrical resistance, indicating that the barrier function of TJs is compromised. These phenotypes were exacerbated by the absence of the Toll-like receptor 3 (TLR3), which initiates double-strand RNA (dsRNA)dependent type I interferon responses $^{74}$. How TLR3 signaling is linked to TJ remodeling is unclear, but type III interferons were recently reported to strengthen epithelial barrier function during Salmonella infection ${ }^{75}$.

Mechanistically, it remains to be determined whether reprogramming of cell signaling pathways or the removal of adhesion components and recruitment to the inclusion or both underlie the disruption of cell-cell junctions. Nevertheless, Chlamydia targeting of cell-cell junctions may drive certain aspects of its pathogenesis, including infertility and ectopic pregnancies. During estrus, the endometrium undergoes extensive paracrinedriven remodeling of cell-cell junctions to permit blastocyst adherence and invasion into the epithelial tissue ${ }^{46}$. Thus, infection-mediated disruption of epithelial cell-cell junctions may impede implantation. Alternatively, Chlamydia infection is associated with elevated expression of the prokineticins receptor 2 (PROKR2), a G protein-coupled receptor that modulates TJ organization and paracellular permeability, which may prime tubal epithelia for implantation in fallopian tubes of patients with ectopic pregnancies ${ }^{76,77}$.

\section{Chlamydia activates epithelial-to-mesenchymal transitions}

The remodeling of epithelial cell-cell junctions is a hallmark of both inflammation and cellular proliferation ${ }^{78}$. New studies indicate that multiple Chlamydia biovars can induce the transformation of epithelial cells to a more mesenchymal-like state by activating the epithelial-to-mesenchymal transition (EMT) program. EMT is essential for organogenesis and tissue repair during which epithelial cells adopt features of cells in the mesenchyme like fibroblasts, altering their polarity and the organization of the actin cytoskeleton and cell-cell adhesions ${ }^{79}$. Driven by growth factors (for example, transforming growth factor beta [TGF- $\beta]$, hepatocyte growth factor, and epidermal growth factor) and hormones (estrogen), EMT can be aberrantly activated during tumorigenesis and inflammation-associated fibrosis $^{78,80}$. Most notably, EMT is often coupled to the downregulation of E-cadherin, upregulation of cell-extracellular matrix (cell-ECM) adhesions, deposition of ECM proteins, and enhanced cell motility. This transition is thought to enable tumor cells to disseminate toward the lymph nodes and vasculature ${ }^{79}$. Alternatively, inflammation-associated EMT is necessary for tissue repair and ceases at the end of the inflammatory response. However, inflammation during chronic infections can lead to sustained EMT, tissue damage, and organ fibrosis ${ }^{81,82}$.

Chlamydia infection can promote EMT in different epithelial subtypes and through multiple pathways. Oviduct epithelial cells infected with $C$. trachomatis serovar D increase the expression of microRNAs (miRNAs) that promote $\mathrm{EMT}^{83}$.
By immunofluorescence microscopy, infection downregulates the expression of E-cadherin while upregulating the EMT markers smooth muscle actin (SMA), the matrix-degrading enzyme matrix metalloproteinase-9 (MMP9), fibronectin, and the transcription factors SNAIL1/2 and ZEB1 ${ }^{83,84}$. Similar results were observed in conjunctival epithelial cells infected with $C$. trachomatis serovar B. Infection increases TGF- $\beta$ expression which signals through SNAIL/ZEB2 and drives the downregulation of E-cadherin and upregulation of fibronectin and SMA. These changes may also involve epigenetic modifications as methylation of E-cadherin, fibronectin, and SMA genes were observed ${ }^{85}$.

More recently, a global phosphoproteomic and transcriptomic analysis in ectocervical epithelial explants infected with C. trachomatis serovar L2 indicated that infection activates cell signaling pathways to promote an EMT-like signature ${ }^{43}$. The infection initiates at the top of the stratified epithelia and progresses toward the basal layer, suggesting that altering cellcell junctions during EMT may provide access for subsequent rounds of infection. Indeed, downstream of the MAPK pathway, the transcriptional factors ETS1 and ERF promote EMT in infected cells, leading to the downregulation of E-cadherin and increased cell motility and invasion ${ }^{43}$. Collectively, these observations suggest that Chlamydia can promote the transformation of epithelial cells, which may contribute to cancers of the cervix and uterus. However, these results must be confirmed in vivo and in the proper tissue context.

\section{Chlamydia infection in new in vivo models}

Extending these observations to a robust animal model of infection has remained challenging. Although the mouse-adapted C. muridarum is used extensively to study the host immune response in mice, this Chlamydia species is less genetically tractable than $C$. trachomatis. On the other hand, intravaginal inoculations of C57BL/6 mice with $C$. trachomatis often fail to induce significant pathology because the bacteria do not efficiently ascend to the upper genital tract ${ }^{86}$. However, transcervical inoculations ${ }^{87}$ that bypass the vaginal vault and the use of more permissive mouse strains (for example, $\mathrm{C} 3 \mathrm{H} / \mathrm{HeJ}$ ) have improved the ability to monitor the infections in the mouse upper genital tract and ensuing pathology and infertility ${ }^{88}$. C. trachomatis serovar L2 ascends to the upper genital tract in $\mathrm{C} 3 \mathrm{H} / \mathrm{HeJ}$ mice when inoculated intravaginally, stimulating a robust immune response and altering epithelial cell height ${ }^{89}$. Future studies combining these new infection models and techniques with both host and bacterial genetics will promote better molecular dissection of Chlamydia pathogenesis in live animals.

\section{Future directions}

The recent advances in the Chlamydia experimental tool kit have brought about a new era in Chlamydia research. With the ability to specifically disrupt genes and express genes in trans, new mechanisms by which Chlamydia subverts its host will be identified. Applying these molecular tools in model systems that better mimic the in vivo physiology will significantly accelerate our understanding of the infection process, especially as these tools are applied to other $C$. trachomatis serovars with distinct tissue tropisms. For example, using more sophisticated infection models and defined $C$. trachomatis mutants, we now test how specific virulence factors promote infection and affect 
epithelial cell growth, function, organization, and potentially transformation. However, more work is necessary to decode the genetics of the urogenital and ocular biovars and generate the relevant in vivo models of infection that best recapitulate the host responses observed in humans. Collectively, these new tools and models can be prioritized for the identification of new therapeutic targets or harnessed for the rational design of vaccines for this clinically important pathogen.
Grant information

This work received funding support from the National Institute of Allergy and Infectious Diseases (grants R01AI134891 and F32AI138372).

The funders had no role in study design, data collection and analysis, decision to publish, or preparation of the manuscript.
1. Horn M: Chlamydiae as symbionts in eukaryotes. Annu Rev Microbiol. 2008; 62 : 113-31.

PubMed Abstract | Publisher Full Text

2. Schachter J: Chlamydial infections (first of three parts). N Engl J Med. 1978; 298(8): 428-35.

PubMed Abstract | Publisher Full Text

3. Bachmann NL, Polkinghorne A, Timms P: Chlamydia genomics: Providing novel insights into chlamydial biology. Trends Microbiol. 2014; 22(8): 464-72. PubMed Abstract | Publisher Full Text

4. Elwell C, Mirrashidi K, Engel J: Chlamydia cell biology and pathogenesis. Nat Rev Microbiol. 2016; 14(6): 385-400.

PubMed Abstract | Publisher Full Text | Free Full Text

5. Mueller KE, Plano GV, Fields KA: New frontiers in type III secretion biology: The Chlamydia perspective. Infect Immun. 2014; 82(1): 2-9.

PubMed Abstract | Publisher Full Text | Free Full Text

6. Betts HJ, Wolf K, Fields KA: Effector protein modulation of host cells: Examples in the Chlamydia spp. arsenal. Curr Opin Microbiol. 2009; 12(1): 81-7. PubMed Abstract | Publisher Full Text

7. Carabeo RA, Dooley CA, Grieshaber SS, et al:: Rac interacts with Abi-1 and WAVE2 to promote an Arp2/3-dependent actin recruitment during chlamydial invasion. Cell Microbiol. 2007; 9(9): 2278-88.

PubMed Abstract | Publisher Full Text

8. Rockey DD, Rosquist JL: Protein antigens of Chlamydia psittaci present in infected cells but not detected in the infectious elementary body. Infect Immun. 1994; 62(1): 106-12.

PubMed Abstract | Free Full Text

9. $\quad F$ Mital J, Lutter El, Barger AC, et al:: Chlamydia trachomatis inclusion membrane protein CT850 interacts with the dynein light chain DYNLT1 (Tctex1). Biochem Biophys Res Commun. 2015; 462(2): 165-70.

PubMed Abstract | Publisher Full Text | Free Full Text | F1000 Recommendation

10. Carpenter V, Chen YS, Dolat L, et al:: The Effector TepP Mediates Recruitment and Activation of Phosphoinositide 3-Kinase on Early Chlamydia trachomatis Vacuoles. $m$ Sphere. 2017; 2(4): pii: e00207-17.

PubMed Abstract | Publisher Full Text | Free Full Text

11. Hackstadt T, Scidmore-Carlson MA, Shaw El, et al.: The Chlamydia trachomatis IncA protein is required for homotypic vesicle fusion. Cell Microbiol. 1999; 1(2): $119-30$.

PubMed Abstract | Publisher Full Text

12. F Derré I, Swiss R, Agaisse H: The lipid transfer protein CERT interacts with the Chlamydia inclusion protein IncD and participates to ER-Chlamydia inclusion membrane contact sites. PLoS Pathog. 2011; 7(6): e1002092. PubMed Abstract | Publisher Full Text | Free Full Text | F1000 Recommendation

13. Agaisse H, Derré I: Expression of the Effector Protein IncD in Chlamydia trachomatis Mediates Recruitment of the Lipid Transfer Protein CERT and the Endoplasmic Reticulum-Resident Protein VAPB to the Inclusion Membrane. Infect Immun. 2014; 82(5): 2037-47.

PubMed Abstract | Publisher Full Text | Free Full Text

14. F Stanhope R, Flora E, Bayne C, et al:: IncV, a FFAT motif-containing Chlamydia protein, tethers the endoplasmic reticulum to the pathogencontaining vacuole. Proc Natl Acad Sci U S A. 2017: 114(45): 12039-12044. PubMed Abstract | Publisher Full Text | Free Full Text | F1000 Recommendation

15. Kumar Y, Valdivia RH: Actin and intermediate filaments stabilize the Chlamydia trachomatis vacuole by forming dynamic structural scaffolds. Cell Host Microbe. 2008; 4(2): 159-69.

PubMed Abstract | Publisher Full Text | Free Full Text

16. Volceanov L, Herbst K, Biniossek M, et al.: Septins Arrange F-Actin-Containing Fibers on the Chlamydia trachomatis Inclusion and Are Required for Normal Release of the Inclusion by Extrusion. mBio. 2014; 5: e460. PubMed Abstract | Publisher Full Text | Free Full Text

17. Wesolowski J, Weber MM, Nawrotek A, et al:: Chlamydia Hijacks ARF GTPases To Coordinate Microtubule Posttranslational Modifications and Golgi Complex
Positioning. mBio. 2017; 8(3): pii: e02280-16

PubMed Abstract | Publisher Full Text | Free Full Text

18. Hybiske K, Stephens RS: Mechanisms of host cell exit by the intracellula bacterium Chlamydia. Proc Natl Acad Sci U S A. 2007; 104(27): 11430-5. PubMed Abstract | Publisher Full Text | Free Full Text

19. Snavely EA, Kokes M, Dunn JD, et al.: Reassessing the role of the secreted protease CPAF in Chlamydia trachomatis infection through genetic approaches. Pathog Dis. 2014; 71(3): 336-51. PubMed Abstract | Publisher Full Text | Free Full Text

20. F Wang Y, Kahane S, Cutcliffe LT, et al:: Development of a Transformation System for Chlamydia trachomatis: Restoration of Glycogen Biosynthesis by Acquisition of a Plasmid Shuttle Vector. PLOS Pathog. 2011; 7(9): e1002258. PublMed Abstract | Publisher Full Text | Free Full Text | F1000 Recommendation

21. Kari L, Goheen MM, Randall LB, et al:: Generation of targeted Chlamydia trachomatis null mutants. Proc Natl Acad Sci U S A. 2011; 108(17): 7189-93. PubMed Abstract | Publisher Full Text | Free Full Text

22. F Kokes M, Dunn JD, Granek JA, et al:: Integrating Chemical Mutagenesis and Whole-Genome Sequencing as a Platform for Forward and Reverse Genetic Analysis of Chlamydia. Cell Host Microbe. 2015; 17(5): 716-25. PubMed Abstract | Publisher Full Text | Free Full Text | F1000 Recommendation

23. Mueller KE, Wolf K, Fields KA: Gene Deletion by Fluorescence-Reported Allelic Exchange Mutagenesis in Chlamydia trachomatis. mBio. 2016; 7(1): e01817-15. PubMed Abstract | Publisher Full Text | Free Full Text

24. Keb G, Hayman R, Fields KA: Floxed-Cassette Allelic Exchange Mutagenesis Enables Markerless Gene Deletion in Chlamydia trachomatis and Can Reverse Cassette-Induced Polar Effects. J Bacteriol. 2018; 200(24): pii: e00479-18. PubMed Abstract | Publisher Full Text | Free Full Text

25. Sixt BS, Bastidas RJ, Finethy R, et al:: The Chlamydia trachomatis Inclusion Membrane Protein CpoS Counteracts STING-Mediated Cellular Surveillance and Suicide Programs. Cell Host Microbe. 2017; 21(1): 113-121. PublMed Abstract | Publisher Full Text | Free Full Text

26. Agaisse $\mathrm{H}$, Derré $\mathrm{I}$ : A C. trachomatis cloning vector and the generation of C. trachomatis strains expressing fluorescent proteins under the control of a C. trachomatis promoter. PLoS One. 2013; 8(2): e57090. PubMed Abstract | Publisher Full Text | Free Full Text

27. Bastidas RJ, Valdivia RH: Emancipating Chlamydia: Advances in the Genetic Manipulation of a Recalcitrant Intracellular Pathogen. Microbiol Mol Biol Rev. 2016; 80(2): 411-27. PubMed Abstract | Publisher Full Text | Free Full Text

28. Rucks EA, Olson MG, Jorgenson LM, et al.: Development of a Proximity Labeling System to Map the Chlamydia trachomatis Inclusion Membrane. Front Cell Infect Microbiol. 2017: 7: 40.

PubMed Abstract | Publisher Full Text | Free Full Text

29. F Dickinson MS, Anderson LN, Webb-Robertson BJM, et al:: Proximitydependent proteomics of the Chlamydia trachomatis inclusion membrane reveals functional interactions with endoplasmic reticulum exit sites. PLOS Pathog. 2019; 15(4): e1007698.

PubMled Abstract | Publisher Full Text | Free Full Text | F1000 Recommendation

30. Aeberhard L, Banhart S, Fischer M, et al.: The Proteome of the Isolated Chlamydia trachomatis Containing Vacuole Reveals a Complex Trafficking Platform Enriched for Retromer Components. PLoS Pathog. 2015; 11(6): e1004883.

PubMed Abstract | Publisher Full Text | Free Full Text

31. Mirrashidi KM, Elwell CA, Verschueren E, et al:: Global Mapping of the Inc-Human Interactome Reveals that Retromer Restricts Chlamydia Infection. Cell Host Microbe. 2015; 18(1): 109-21.

PubMed Abstract | Publisher Full Text | Free Full Text

32. Kaddoum L, Magdeleine E, Waldo GS, et al:: One-step split GFP staining for sensitive protein detection and localization in mammalian cells. BioTechniques. 2010; 49(4): 727-8, 730, 732 passim. PubMed Abstract | Publisher Full Text 
33. Wang X, Hybiske K, Stephens RS: Direct visualization of the expression and localization of chlamydial effector proteins within infected host cells. Pathog Dis. 2018; 76(2)

PubMed Abstract | Publisher Full Text | Free Full Text

34. Nans A, Saibil HR, Hayward RD: Pathogen-host reorganization during Chlamydia invasion revealed by cryo-electron tomography. Cell Microbiol. 2014 16(10): 1457-72.

PubMed Abstract | Publisher Full Text | Free Full Text

35. Lee JK, Enciso GA, Boassa D, et al.: Replication-dependent size reduction precedes differentiation in Chlamydia trachomatis. Nat Commun. 2018; 9(1): 45 PubMed Abstract | Publisher Full Text | Free Full Text

36. Taylor BD, Haggerty CL: Management of Chlamydia trachomatis genital trac infection: Screening and treatment challenges. Infect Drug Resist. 2011; 4: $19-29$.

PubMed Abstract | Publisher Full Text | Free Full Text

37. Blaskewicz CD, Pudney J, Anderson DJ: Structure and function of intercellular junctions in human cervical and vaginal mucosal epithelia. Biol Reprod. 2011; 85(1): 97-104.

PubMed Abstract | Publisher Full Text | Free Full Text

38. Guseva NV, Dessus-Babus S, Moore CG, et al.: Differences in Chlamydia trachomatis Serovar E Growth Rate in Polarized Endometrial and Endocervical Epithelial Cells Grown in Three-Dimensional Culture. Infect Immun. 2007; 75(2): $553-64$

PubMed Abstract | Publisher Full Text | Free Full Text

39. Moore ER, Fischer ER, Mead DJ, et al:: The chlamydial inclusion preferentially intercepts basolaterally directed sphingomyelin-containing exocytic vacuoles. Traffic. 2008; 9(12): 2130-40

PubMed Abstract | Publisher Full Text | Free Full Text

40. Herbst-Kralovetz MM, Quayle AJ, Ficarra M, et al:: Quantification and comparison of toll-like receptor expression and responsiveness in primary and immortalized human female lower genital tract epithelia. Am J Reprod Immunol. 2008; 59(3): 212-24

PubMed Abstract | Publisher Full Text

41. Buckner LR, Lewis ME, Greene SJ, et al:: Chlamydia trachomatis infection results in a modest pro-inflammatory cytokine response and a decrease in T cell chemokine secretion in human polarized endocervical epithelial cells. Cytokine. 2013; 63(2): 151-65

PubMed Abstract | Publisher Full Text | Free Full Text

42. Kessler M, Zielecki J, Thieck O, et al.: Chlamydia trachomatis Disturbs Epithelia Tissue Homeostasis in Fallopian Tubes via Paracrine Wnt Signaling. Am J Pathol. 2012; 180(1): 186-98.

PubMed Abstract | Publisher Full Text

43. Zadora PK, Chumduri C, Imami K, et al:: Integrated Phosphoproteome and Transcriptome Analysis Reveals Chlamydia-Induced Epithelial-toMesenchymal Transition in Host Cells. Cell Rep. 2019; 26(5): 1286-1302.e8. PubMed Abstract | Publisher Full Text

44. F Kessler M, Hoffmann K, Brinkmann V, et al:: The Notch and Wnt pathways regulate stemness and differentiation in human fallopian tube organoids. Nat Commun. 2015; 6: 8989 .

PubMed Abstract | Publisher Full Text | Free Full Text | F1000 Recommendation

45. F Kessler M, Hoffmann K, Fritsche K, et al:: Chronic Chlamydia infection in human organoids increases stemness and promotes age-dependent $\mathrm{CpG}$ methylation. Nat Commun. 2019; 10(1): 1194.

PubMed Abstract | Publisher Full Text | Free Full Text | F1000 Recommendation

46. Grund S, Grümmer R: Direct Cell-Cell Interactions in the Endometrium and in Endometrial Pathophysiology. Int J Mol Sci. 2018; 19(8): pii: E2227. PubMed Abstract | Publisher Full Text | Free Full Text

47. Someya M, Kojima T, Ogawa M, et al:: Regulation of tight junctions by sex hormones in normal human endometrial epithelial cells and uterus cancer cell line Sawano. Cell Tissue Res. 2013; 354(2): 481-94. PubMed Abstract | Publisher Full Text

48. Garcia MA, Nelson WJ, Chavez N: Cell-Cell Junctions Organize Structural and Signaling Networks. Cold Spring Harb Perspect Biol. 2018; 10(4): pii: a029181. PubMed Abstract | Publisher Full Text | Free Full Text

49. Zihni C, Balda MS, Matter K: Signalling at tight junctions during epithelial differentiation and microbial pathogenesis. J Cell Sci. 2014; 127(Pt 16): 3401-13. PubMed Abstract | Publisher Full Text

50. Zihni $\mathrm{C}$, Mills $\mathrm{C}$, Matter $\mathrm{K}$, et al:: Tight junctions: From simple barriers to multifunctional molecular gates. Nat Rev Mol Cell Biol. 2016; 17(9): 564-80. PubMed Abstract | Publisher Full Text

51. Nelson WJ: Regulation of cell-cell adhesion by the cadherin-catenin complex. Biochem Soc Trans. 2008; 36(Pt 2): 149-55.

PubMed Abstract | Publisher Full Text | Free Full Text

52. F Buckley CD, Tan J, Anderson KL, et al.: Cell adhesion. The minimal cadherin-catenin complex binds to actin filaments under force. Science. 2014 346(6209): 1254211

PubMed Abstract | Publisher Full Text | Free Full Text | F1000 Recommendation

53. F Benham-Pyle BW, Pruitt BL, Nelson WJ: Cell adhesion. Mechanical strain induces $\mathrm{E}$-cadherin-dependent Yap1 and $\beta$-catenin activation to drive cell cycle entry. Science. 2015; 348(6238): 1024-7.

PubMed Abstract | Publisher Full Text | Free Full Text | F1000 Recommendation

54. Takai $\mathrm{Y}$, Nakanishi $\mathrm{H}$ : Nectin and afadin: novel organizers of intercellular junctions. J Cell Sci. 2003; 116(Pt 1): 17-27.

PubMed Abstract | Publisher Full Text

55. Rikitake $Y$, Mandai K, Takai $Y$ : The role of nectins in different types of cell-cell adhesion. J Cell Sci. 2012; 125(Pt 16): 3713-22.

PubMed Abstract | Publisher Full Text

56. F Nekrasova O, Green KJ: Desmosome assembly and dynamics. Trends Cell . 2013; 23(11): 537-46.

PubMed Abstract | Publisher Full Text | Free Full Text | F1000 Recommendation

57. Bonazzi M, Cossart P: Impenetrable barriers or entry portals? The role of cellcell adhesion during infection. J Cell Biol. 2011; 195(3): 349-58. PubMed Abstract | Publisher Full Text | Free Full Text

58. Lecuit M, Dramsi S, Gottardi C, et al:: A single amino acid in E-cadherin responsible for host specificity towards the human pathogen Listeria monocytogenes. EMBO J. 1999; 18(14): 3956-63. PubMed Abstract | Publisher Full Text | Free Full Text

59. F Evans MJ, von Hahn T, Tscherne DM, et al.: Claudin-1 is a hepatitis $\mathbf{C}$ virus co-receptor required for a late step in entry. Nature. 2007; 446(7137): 801-5. PubMed Abstract | Publisher Full Text | F1000 Recommendation

60. McNamara BP, Koutsouris A, O'Connell CB, et al.: Translocated EspF protein from enteropathogenic Escherichia coli disrupts host intestinal barrier function. J Clin Invest. 2001; 107(5): 621-9. PubMed Abstract | Publisher Full Text | Free Full Text

61. König J, Wells J, Cani PD, et al.: Human Intestinal Barrier Function in Health and Disease. Clin Transl Gastroenterol. 2016; 7(10): e196. PubMed Abstract | Publisher Full Text | Free Full Text

62. Prozialeck WC, Fay MJ, Lamar PC, et al.: Chlamydia trachomatis disrupts Ncadherin-dependent cell-cell junctions and sequesters beta-catenin in human cervical epithelial cells. Infect Immun. 2002; 70(5): 2605-13.

PubMed Abstract | Publisher Full Text | Free Full Text

63. Cadigan KM, Peifer M: Wnt signaling from development to disease: insights from model systems. Cold Spring Harb Perspect Biol. 2009; 1(2): a002881. PubMed Abstract | Publisher Full Text | Free Full Text

64. Kintner J, Moore CG, Whittimore JD, et al:: Inhibition of Wnt Signaling Pathways Impairs Chlamydia trachomatis Infection in Endometrial Epithelial Cells. Front Cell Infect Microbiol. 2017; 7: 501. PubMed Abstract | Publisher Full Text | Free Full Text

65. Bartlett JG: Diagnostic tests for agents of community-acquired pneumonia. Clin Infect Dis. 2011; 52 Suppl 4: S296-304. PubMed Abstract | Publisher Full Text

66. Flores R, Zhong G: The Chlamydia pneumoniae Inclusion Membrane Protein Cpn1027 Interacts with Host Cell Wnt Signaling Pathway Regulator Cytoplasmic Activation/Proliferation-Associated Protein 2 (Caprin2). PLOS One. 2015; 10(5): e0127909.

PubMed Abstract | Publisher Full Text | Free Full Text

67. Liu J, Miao G, Wang B, et al:: Chlamydia pneumoniae infection promotes monocyte transendothelial migration by increasing vascular endothelial cell permeability via the tyrosine phosphorylation of VE-cadherin. Biochem Biophys Res Commun. 2018; 497(2): 742-8. PubMed Abstract | Publisher Full Text

68. Potter MD, Barbero S, Cheresh DA: Tyrosine phosphorylation of VE-cadherin prevents binding of p120-and beta-catenin and maintains the cellular mesenchymal state. J Biol Chem. 2005; 280(36): 31906-12. PubMed Abstract | Publisher Full Text

69. Lane BJ, Mutchler C, Al Khodor S, et al.: Chlamydial entry involves TARP binding of guanine nucleotide exchange factors. PLoS Pathog. 2008; 4(3): e1000014. PubMed Abstract | Publisher Full Text | Free Full Text

70. Giampietro C, Disanza A, Bravi L, et al.: The actin-binding protein EPS8 binds VE-cadherin and modulates YAP localization and signaling. J Cell Biol. 2015; 211(6): 1177-92.

PubMed Abstract | Publisher Full Text | Free Full Text

71. Fredriksson $\mathrm{K}$, van Itallie $\mathrm{CM}$, Aponte $\mathrm{A}$, et al:: Proteomic analysis of proteins surrounding occludin and claudin-4 reveals their proximity to signaling and trafficking networks. PLOS One. 2015; 10(3): e0117074. PubMed Abstract | Publisher Full Text | Free Full Text

72. Lie PP, Mruk DD, Lee WM, et al.: Epidermal growth factor receptor pathway substrate 8 (Eps8) is a novel regulator of cell adhesion and the blood-testis barrier integrity in the seminiferous epithelium. FASEB J. 2009; 23(8): 2555-67. PubMed Abstract | Publisher Full Text | Free Full Text

73. Kumar R, Gong H, Liu L, et al.: TLR3 deficiency exacerbates the loss of epithelial barrier function during genital tract Chlamydia muridarum infection. PLoS One. 2019; 14(1): e0207422.

PubMed Abstract | Publisher Full Text | Free Full Text

74. Medzhitov R: Toll-like receptors and innate immunity. Nat Rev Immunol. 2001; 1(2): 135-45.

PubMed Abstract | Publisher Full Text

75. Odendall C, Voak AA, Kagan JC: Type III IFNs Are Commonly Induced by Bacteria-Sensing TLRs and Reinforce Epithelial Barriers during Infection. J Immunol. 2017; 199(9): 3270-9.

PubMed Abstract | Publisher Full Text | Free Full Text

76. Shaw JL, Wills GS, Lee KF, et al.: Chlamydia trachomatis infection increases fallopian tube PROKR2 via TLR2 and NFKB activation resulting in a microenvironment predisposed to ectopic pregnancy. Am J Pathol. 2011 
178(1): 253-60.

PubMed Abstract | Publisher Full Text | Free Full Text

77. Guilini C, Urayama K, Turkeri G, et al: Divergent roles of prokineticin receptors in the endothelial cells: angiogenesis and fenestration. Am J Physiol Heart Circ Physiol. 2010; 298(3): H844-52.

PubMed Abstract | Publisher Full Text

78. Kalluri $R$, Weinberg RA: The basics of epithelial-mesenchymal transition. J Clin Invest. 2009; 119(6): 1420-8.

PubMed Abstract | Publisher Full Text | Free Full Text

79. Thiery JP, Acloque H, Huang RY, et al.: Epithelial-mesenchymal transitions in development and disease. Cell. 2009; 139(5): 871-90. PubMed Abstract | Publisher Full Text

80. Eger A, Stockinger A, Schaffhauser B, et al:: Epithelial mesenchymal transition by $c$-Fos estrogen receptor activation involves nuclear translocation of betacatenin and upregulation of beta-catenin/lymphoid enhancer binding factor-1 transcriptional activity. J Cell Biol. 2000; 148(1): 173-88. PubMed Abstract | Publisher Full Text | Free Full Text

81. López-Novoa JM, Nieto MA: Inflammation and EMT: an alliance towards organ fibrosis and cancer progression. EMBO Mol Med. 2009; 1(6-7): 303-14. PubMed Abstract | Publisher Full Text | Free Full Text

82. Hofman P, Vouret-Craviari V: Microbes-induced EMT at the crossroad of inflammation and cancer. Gut Microbes. 2012; 3(3): 176-85. PubMed Abstract | Publisher Full Text | Free Full Text

83. Igietseme JU, Omosun Y, Stuchlik O, et al:: Role of Epithelial-Mesenchyme Transition in Chlamydia Pathogenesis. PLoS One. 2015; 10(12): e0145198. PubMed Abstract | Publisher Full Text | Free Full Text
84. Igietseme JU, Omosun Y, Nagy T, et al.: Molecular Pathogenesis of Chlamydia Disease Complications: Epithelial-Mesenchymal Transition and Fibrosis. Infect Immun. 2018; 86(1): pii: e00585-17.

PubMed Abstract | Publisher Full Text | Free Full Text

85. Rajić J, Inic-Kanada A, Stein E, et al:: Chlamydia trachomatis Infection Is Associated with E-Cadherin Promoter Methylation, Downregulation of ECadherin Expression, and Increased Expression of Fibronectin and $\alpha$-SMAImplications for Epithelial-Mesenchymal Transition. Front Cell Infect Microbiol. 2017; 7: 253 .

2017; 7: 253.
PubMed Abstract | Publisher Full Text | Free Full Text

86. Sturdevant GL, Caldwell HD: Innate immunity is sufficient for the clearance of Chlamydia trachomatis from the female mouse genital tract. Pathog Dis. 2014; 72(1): 70-3.

PubMed Abstract | Publisher Full Text | Free Full Text

87. Coers J, Gondek DC, Olive AJ, et al: Compensatory T cell responses in IRGdeficient mice prevent sustained Chlamydia trachomatis infections. PLOS Pathog. 2011; 7(6): e1001346.

PubMed Abstract | Publisher Full Text | Free Full Text

88. Pal S, Tifrea DF, Zhong G, et al: Transcervical Inoculation with Chlamydia trachomatis Induces Infertility in HLA-DR4 Transgenic and Wild-Type Mice. Infect Immun. 2018; 86(1): pii: e00722-17.

PubMed Abstract | Publisher Full Text | Free Full Text

89. Shaw JH, Behar AR, Snider TA, et al:: Comparison of Murine Cervicovaginal Infection by Chlamydial Strains: Identification of Extrusions Shed In vivo. Front Cell Infect Microbiol. 2017; 7: 18 .

PubMed Abstract | Publisher Full Text | Free Full Text 


\section{Open Peer Review}

\section{Current Peer Review Status:}

\section{Editorial Note on the Review Process}

Faculty Reviews are review articles written by the prestigious Members of Faculty Opinions. The articles are commissioned and peer reviewed before publication to ensure that the final, published version is comprehensive and accessible. The reviewers who approved the final version are listed with their names and affiliations.

\section{The reviewers who approved this article are:}

\section{Version 1}

\section{Ming Tan}

Departments of Microbiology and Molecular Genetics, and Medicine, University of California, Irvine, California, USA

Competing Interests: No competing interests were disclosed.

\section{Kenneth Fields}

Department of Microbiology, Immunology \& Molecular Genetics, University of Kentucky College of Medicine, Kentucky, USA

Competing Interests: No competing interests were disclosed.

\section{Peter Timms}

Faculty of Science, Health, Education and Engineering, University of the Sunshine Coast, Queensland, Australia

Competing Interests: No competing interests were disclosed.

The benefits of publishing with F1000Research:

- Your article is published within days, with no editorial bias

- You can publish traditional articles, null/negative results, case reports, data notes and more

- The peer review process is transparent and collaborative

- Your article is indexed in PubMed after passing peer review

- Dedicated customer support at every stage

For pre-submission enquiries, contact research@f1000.com 